\title{
Driving Forces of Remittance Inflow in Bangladesh: An Empirical Study
}

\author{
Mohammed Saiful Islam ${ }^{1} \&$ Shamima Nasrin ${ }^{2}$ \\ ${ }^{1}$ Chittagong University, Bangladesh \\ ${ }^{2}$ International Islamic University Chittagong, Bangladesh \\ Correspondence: Mohammed Saiful Islam, Chittagong University, Bangladesh. E-mail: saifulcu@yahoo.com
}

Received: March 19, 2015

Accepted: April 22, 2015

Online Published: May 25, 2015

doi:10.5539/ijef.v7n6p126

URL: http://dx.doi.org/10.5539/ijef.v7n6p126

\begin{abstract}
This paper empirically investigates the major driving forces of remittance inflow in Bangladesh. Using annual data over the period from 1977 to 2011 the paper concludes that gross domestic products of host country and domestic country, exchange rate, petroleum price and skill of labour significantly influence remittance inflow in Bangladesh. One finding of the research is that skilled labour force rather sends smaller amount of remittance to the home country than the unskilled labour. This is due to the fact that skilled people do not maintain close tie with the home country because they often take their families with them to foreign countries where they work. Because of narrow opportunities, unskilled labour cannot take their families with them and hence send money to their families. The study also identifies the reason behind migration of manpower from Bangladesh to foreign countries. Presence of surplus labour, slim job opportunity, unfavourable working environment, poor wage rate, inadequate social security and political instability largely induce people to migrate abroad.
\end{abstract}

Keywords: devaluation, elasticity, foreign currency reserve, migration, remittance, stationarity

\section{Introduction}

Remittance inflow in Bangladesh is one of the prime sources of foreign currency reserve. A certain amount of foreign currency reserve is indeed a vital need for the country because of its high degree of dependency on import. Inflow of remittance depends on the amount of manpower migration. International migration is a worldwide phenomenon through which remittance is channeled into the respective country from which migration takes place. In Bangladesh remittance is the second largest sector of foreign exchange earnings after readymade garments (RMG) sector (Kuntal, 2010). According to the recent statistics, on average there is a fifteen to twenty percent annual increase in remittance. World Bank reports that in 2012 Bangladesh retained its position as the seventh most remittance-earning country. A study conducted by International Organization for Migration (IOM) reveals that remittance earned by Bangladesh is nearly five times the size of foreign aid and nine times the size of foreign direct investment (FDI) and contributes more than 10 percent to gross domestic product (GDP). The IOM study also reports that the migrants are less skilled, inefficient in English language and lack certified training. The remittance sent by the migrants, however, contributes a great deal to economic development of Bangladesh. It is therefore important to identify the determinants of remittance inflow in Bangladesh.

The number of papers investigating the determinants of remittance is very few. However, several papers have examined inflation, migration, GDP of host countries, financial sector development etc. as the determinants of remittance. This paper examines the determinants of remittance empirically. The rest of the paper is organized as follows. Section 2 describes the objectives of the study. Section 3 presents the previous literatures on the current issue. Section 4 reveals the source of data and illustrates the methodology used. Empirical results have been discussed in section 5 and section 6 concludes with some policy recommendations.

\section{Objective of the Study}

The main purpose of the study is to find out the determinants of remittance inflow in Bangladesh for which it is necessary to build up a theoretical framework first. Empirical determination of the determinants requires the use of a suitable regression model. In order to assess the degree of dependency of remittance on the relevant variables, elasticity of remittance with respect to the corresponding variable would be estimated. This step will also help to test whether relationships among variables are statistically significant or not. These tests will be 
done applying econometric techniques. Finally the paper aims at presenting the best possible ways to ensure stability of economic growth through the stability of remittance inflow.

\section{Literature Review}

\subsection{Theory of Remittance}

Theories of remittances are based on pessimistic and optimistic views. An optimist says remittance is a gain to the receiving countries that could alleviate poverty and stimulate economic development and ease pressure on governments burdened with large external deficits. Conversely, a pessimist says that remittances should not be encouraged, as it is disadvantageous to the growth and development of the receiving countries. From a pessimists point of view remittances are responsible for excessive consumption, import dependency and unproductive investment in housing and land.

Neoclassical theory says that free labour migration would lead to inadequacy of labour, higher marginal productivity of labour and increase in wage levels in migrant-sending societies. Neo-Marxist theory states that migration and remittances produce and reinforce the capitalist system based on inequalities. This is because migration changes the local taste of migrants' families and increase the demand for foreign goods.

Social network theory emphasizes the social rather than the economic role that remittances play in the lives of the migrants and their families, where social network is defined as a set of recurrent association between groups of people linked by occupational, familial, cultural or affective ties.

\subsection{Causes of Migration}

People migrate for diverse reasons. These reasons can be classified as economiic, social, political or environmental. Push and pull factors are often used to explain the reason behind migration. Push factors are the reasons why people leave an area, i.e. what pushes them away from their home. Push factors take account of lack of services, lack of safety, crime, crop failure, drought, flooding, poverty and war. Rapid growth of population may be viewed as a push factor for migration. Pull factors are the reasons why people move to a particular area, i.e. what pulls them to a new place. Pull factors include higher employment, abundance of resources, better services, good climate, safety and security, political stability, fertile land, lower risk of natural hazards. Migration usually happens as a result of a combination of these two factors.

Ratha (2004) stated that fiscal incentives are also responsible for migration. The paper argues that the majority of developing countries offer tax incentives to attract remittances. Because of various reasons for migration, remittances have become a significant source of resource transfer in the Bangladesh economy. Bangladesh has continued as a trade deficit country in most of the years since independence but from 2000 it has been endlessly posting current account surplus which is the gap between exports and imports of goods, services, and unrequited transfers but mainly because of remittance income (Munim, 2012).

\subsection{Recruitment Process of Workers Abroad}

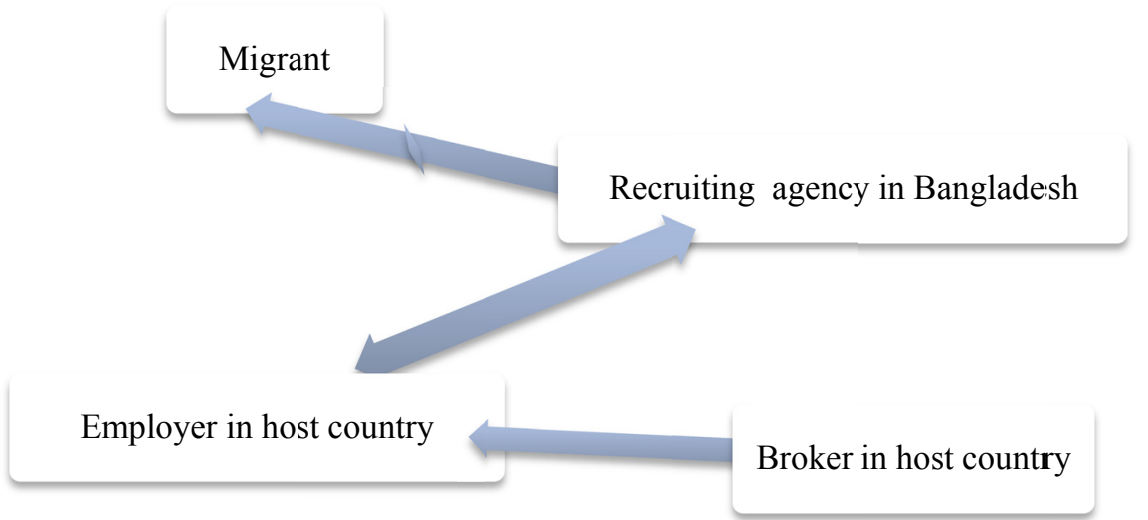

Figure 1. The process of migration

The migrants are the remittance senders. But the process of migration in the context of Bangladesh is not smooth, sometimes it is not fair even. The process of migration involves a number of persons, institutions and agencies. 
These institutions are both governmental and private or local and foreign. The private agencies avail license from the government and collect information on foreign demand for labour. The agencies then recruit workers as per specifications of the foreign employers and then process their cases for placement.

The recruiting agencies are organized under the Bangladesh Association of International Recruiting Agencies (BAIRA). The Association was formed in December 1984 with representatives of twenty-three recruiting agencies. Figure 1 shows the process of migration in Bangladesh.

\subsection{Channels of Remitting}

Both formal and informal channels are being used by Bangladeshi migrants to send their remittances to their relatives at home. Remittance is sent formally through various ways such as demand draft, traveller's check, telegraphic transfer, postal order, and direct transfer, Automatic teller machine (ATM) etc (Roy, 2010). Bangladesh Bank issues licenses to commercial banks to make transaction with foreign banks and exchange houses for assisting in sending remittances by Bangladeshi nationals living abroad. Persons who are willing to remit money to their families through formal channels can simply buy either Taka draft or US dollar draft from these foreign banks and exchange houses. Bangladeshi nationals who are living abroad can also send foreign exchange very easily and directly to their own bank account or to their nominated person's bank account in Bangladesh. Currently this banking service has become more proactive towards crediting the proceeds of remittances to beneficiary's account.

Among the informal ways, the widely used one is hundi system. Hundi refers to the illegal money transfer system which involves tax evasion and it is devoid of foreign exchange rules and regulations. As opposed to the informal way of sending remittance the formal means including mobile banking are getting popularity among the remitters.

\subsection{Proper Utilization of Remittances}

Remittances have both productive and unproductive use. Productive use refers to the use that increases the productive capacity and generates income to the households. And the unproductive use does not help accumulate capital or generate further income. Barai (2012) views consumption as the unproductive use of remittance and investment as productive use of remittance.

A Bangladesh Bank survey results are documented in Table 1, which shows the sector-wise spending of remittances pertaining to consumption alone.

Table 1. Overall scenario of uses of remittances in consumption

\begin{tabular}{lcc}
\hline Description & Percentage uses of remittance in different categories & Number of families \\
\hline To buy food & 75 & 2265 \\
To repayment of loan & 42 & 1276 \\
Educational expenses of family members & 65 & 1949 \\
Medical and health & 57 & 1701 \\
Marriage and other occasions & 40 & 1205 \\
Court cases & 4 & 112 \\
\hline
\end{tabular}

Source: Bangladesh Bank, Research department.

Table 2 shows the use of remittances for investment purposes. This is evident that the families of the migrants prefer to buy land or flat. To them, this type of investment is less risky.

Table 2. Overall scenario of uses of remittances in investment sector (productive and unproductive sector)

\begin{tabular}{lcc}
\hline Classification of Investment & $\begin{array}{c}\text { Number of families } \\
\text { using remittance }\end{array}$ & $\begin{array}{c}\text { Percentage of number of } \\
\text { families using remittance }\end{array}$ \\
\hline Investment in Productive Sector & & 42 \\
Buying land or flat & 1252 & 13 \\
Bond & 392 & 21 \\
Savings in Bank/institutions/time deposit and insurance & 638 & 1 \\
loan giving based on interest & 20 & 12 \\
personal business & 371 & \\
\hline
\end{tabular}




\begin{tabular}{lcc}
\hline Joint business & 74 & 2 \\
Sending family members abroad & 547 & 18 \\
\hline & Investment in Non-Productive Sector & 39 \\
\hline To reconstruct houses & 1182 & 5 \\
Buying car/motorcycle & 136 & 8 \\
Investing money in capital market & 226 & 3 \\
Spending money to create employment for others. & 89 & \\
\hline
\end{tabular}

Source: Bangladesh Bank, Research department.

\subsection{Challenges Faced by Bangladeshi Migrants}

People who are migrating play a significant role in the national economy through earning foreign currency but they face multiple problems at home and abroad. Because of lack of education they do not know how to accomplish official formalities properly. Moreover, during their stay in abroad they fail to comply with the host countries rules and requirements. Due to this latter loophole they become illegal in the host countries at a certain point of time. In practice most of the labours who migrate abroad are poor and therefore it is very tough for them to bear the expenses of migration. Some of them sales land, mortgage their houses, take loans from relatives or banks etc. A survey conducted by Bangladesh bank research team finds the following sources of financing migration cost.

Table 3. Sources of collecting money to bear migration cost

\begin{tabular}{lcc}
\hline Description & Number of families & Percentage (families) \\
\hline Land Sale/ Mortgage & 1244 & 41 \\
Institutional/non-institutional loan & 321 & 11 \\
Borrow money from relatives & 1415 & 47 \\
Contract signed to repayment of loan from earning of migrant's & 266 & 9 \\
Sales ornaments & 218 & 7 \\
Cash from own family & 348 & 12 \\
Others & 108 & 4 \\
\hline
\end{tabular}

Source: Bangladesh Bank Research.

\subsection{Source of Remittance}

Most of the expatriates work in Saudi Arabia, the UAE, the UK, Kuwait, and the USA. Besides, new employment opportunities for Bangladeshi workers have also been created in Libya, Qatar, Oman, Singapore, Germany, Bahrain, Iran, Japan and many other countries. Since 1993 Malaysia and since 2001 Australia, Italy, South Korea and Hong Kong are also importing workers from Bangladesh. Saudi Arabia absorbs highest number of labour from Bangaldesh. Malaysia is the second largest employer of Bangladeshi workers. Figure 2 displays the comparative picture of migrant receiving countries. 


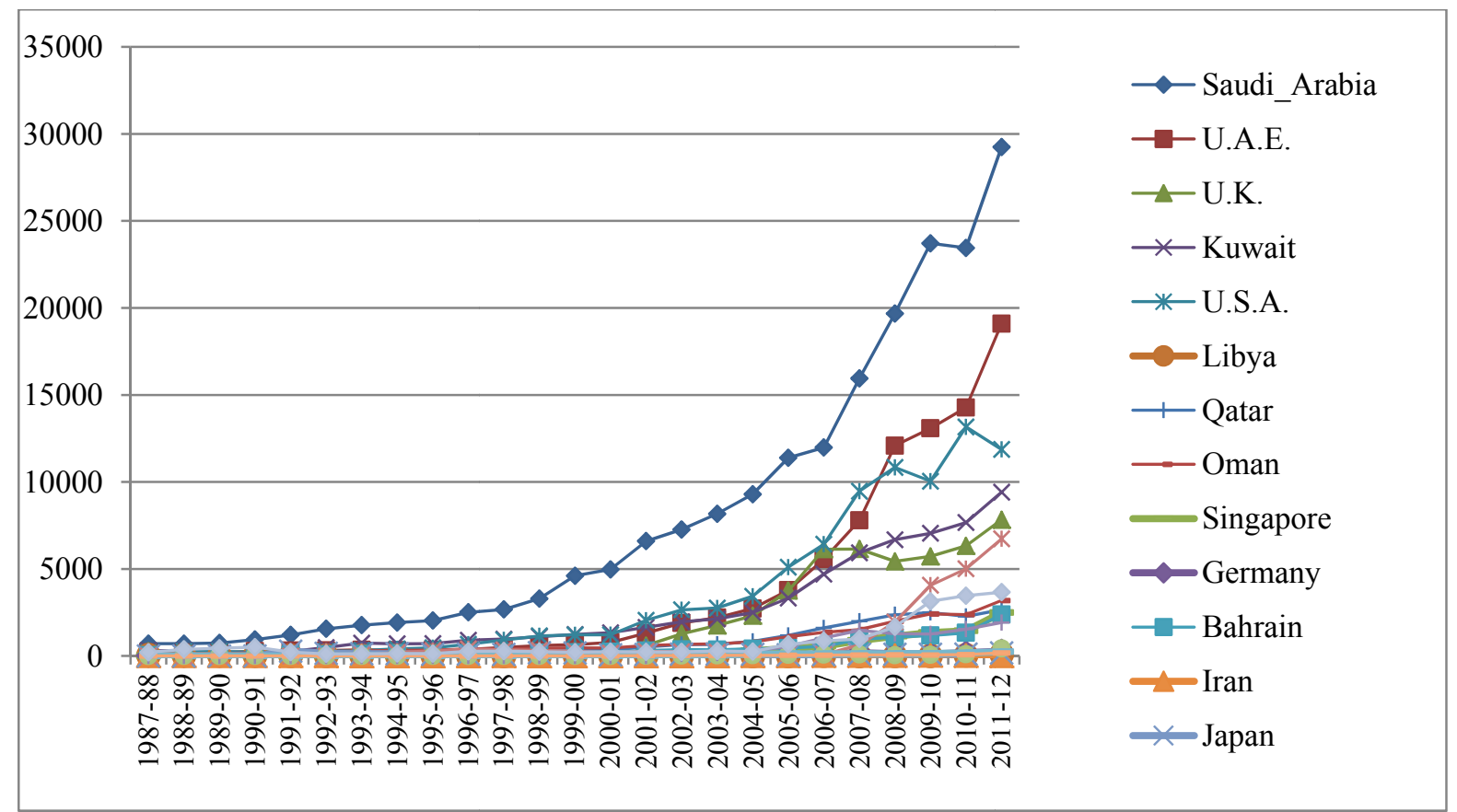

Figure 2. Trend of country- wise migration

Source: Bangladesh bank 2012.

\subsection{Flow of Remittance Earning}

Remittance income is incredibly important for any developing country like Bangladesh as the country endeavors to lower the dependence on foreign aid. Rahim (2013) states that remittances have been identified as one of the three factors that have been responsible for reducing the overall incidence of poverty in Bangladesh. According to Bangladesh bank report, Bangladesh has received about Taka 101882.7786 Crore in 2011. According to BMET, during the last 35 years (1977-2011) Bangladesh has experienced a steady rise in remittance growth. It was only $\$ 101.98$ million in 1977 , whereas it has reached at $\$ 12843.43$ million in 2011 . Figure 3 shows the trend of remittance inflow in Bangladesh since 1977.

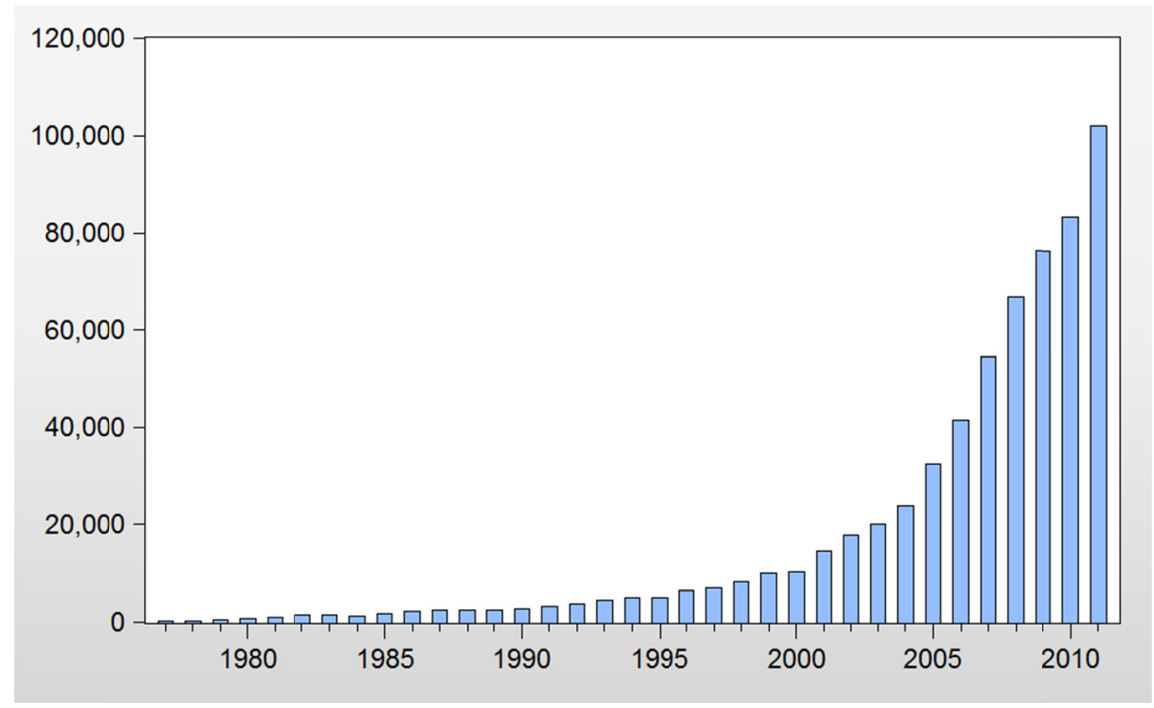

Figure 3. Flow of remittance earning (in Crore Taka)

Source: BMET (Bureau of Manpower, Employment and Training). 
A few studies investigated the prime determinants of remittance. Among many others, home and host country income, exchange rate, financial sector development and inflation rate have significant impacts on remittance inflows in Bangladesh. There are, however, a few microeconomic determinants of remittance like the size of the household of the remitter, sex of the migrant etc.

Barua (2007) conducted an empirical study in which it has been deduced that there is a positive correlation between income differential of home and host country and inflow of remittance. On the other hand inflation differential shows the opposite relation. Author also considered devaluation of domestic currency as a macroeconomic variable which is also positively correlated with remittance inflow. Hasan (2008) found the significant impact of inflation, interest rate, exchange rate of Bangladesh and GDP of five remittance sending countries. The paper concluded that if the domestic interest rate goes up by 1 percent on average then the remittance will increase by 1.94 percent. Again if the GDP of five countries increases by 1 percent, then remittance will increase by 3.06 percent. Emmanuel, William, Gladys, and Yuni (2012) said, the working status of the migrant may depend on the macroeconomic conditions in the country of residence. Mahtab (2012), in his empirical research, found that income of household, household size do not influence foreign remittance sent by migrant workers but duration of staying abroad, exchange motive and investment motive do influence workers' remittance. Singh, Haacker, and Lee (2009) found that the wealthier the country of origin of the expatriates the higher the remittances they send back home. Naufal and Termos (2009) examined the responsiveness of remittances to oil price in GCC countries. They examined this responsiveness in remitting countries and found that oil price elasticity of remittances is around 0.4 .

Some studies concentrate on migrant's efficiency as because remittance depends not only on number of migrants but also on their efficiency level. Microfinance Institutions (MFIs) can train migrant workers according to their importers' demand which will help workers to improve their efficiency (Alam, 2012).

Nurnaher Rani (2012) studied the behavior of remittance inflows in Bangladesh and tried to find out its determinants. Using yearly data from 1981 to 2011, the paper concludes that various regulatory and institutional arrangements taken by the government and the Bangladesh bank influence remittance flow in Bangladesh. Faini and Riccardo (2007) finds that skilled migrants remit less than unskilled migrants as skilled migrants bring their families abroad and spend more time there. Migration of skilled labor is the brain drain of developing countries and reduces the flow of remittances. Manuel (2009) identifies global recession as a major hindrance to remittance inflow. Migrants lose their jobs, earn less and become direct victims of the housing crisis during recession. The U.S. economic recession has affected all workers, migrants including the skilled ones. Correct identification of the determinants of remittance inflow in Bangladesh has important bearing on individuals and on the economy as a whole. In this paper we put effort to identify the factors that influence remittance earning of Bangladeshi expatriates. Econometric techniques have been employed in reaching the goal of the study.

\section{Data and Methodology}

\subsection{Source of Data}

Data employed in the research paper are secondary in nature. The annual data for the period 1977-2011 have been used in the research. 1977 has been selected as the starting year because Bangladesh started migrating workers from this year. The annual data have been collected from various sources as follows.

- WDI (World development Indicators) database;

- $\quad$ Economic trend (Bangladesh Bank);

- Bangladesh Economic Survey (Ministry of Finance);

- Organization of the Petroleum Exporting Countries (OPEC);

- Bureau of Manpower, Employment and Training (BMET).

In our paper Remittance Inflow (REM) refers to transfer of money by a foreign worker to his or her home country or simply sending amount from one country to another. Money sent home by migrants constitutes the second largest financial inflow for many developing countries exceeding international aid. For Bangladesh the most manpower importing countries are: KSA, UAE, Kuwait etc. Main source of data is Bangladesh Bank. Exchange rate (EXC) refers to Taka/dollar exchange rate. Data for exchange rate has been collected from WDI (official rate). If the exchange rate of the home country depreciates the remittance inflow will increase. Migration (MIG) refers to the number of persons staying abroad for their family and livelihoods. It is commonly believed that increase in the number of migrant workers abroad is positively correlated with remittance inflow implying that growing number of migrants abroad contribute to higher level of remittances. Petroleum price (PP) 
has been used to estimate the elasticity of remittances with respect to price of crude oil. It is expected that there is a positive relation between petroleum price and remittance inflow. Bangladesh started to export manpower abroad, particularly in Middle East countries, following oil price boom in the early 1970s. Because of labor shortage during 1977-2011, countries had to import foreign labor to gear up huge development activities financed by surplus oil revenues. Since then the number of migrants has been growing steadily. So petroleum price is the likely determinant of remittance inflows. GDP of host country (GDPh) is a simple average value of 7 countries GDP. The countries where most of the migrants are destined are viewed as the host countries. The host countries are Saudi Arabia, United Arab Emirates, United Kingdom, United States, Kuwait, Oman, and Qatar. There is a positive relationship between host country's GDP and remittance inflow. If the host country's GDP increases, the remittance inflow in domestic country will increase. Domestic country's GDP is denoted as GDPd.

Since the paper uses time series data, unit root tests have been performed in order to check the stationarity of the variables.

\subsection{Specification of the Model}

Log-log model used by Nurnaher and Rama (2012) as well as Nabi (2011) has been used in this research to identify the determinants of remittance inflow in Bangladesh. The following two models have been estimated in pursuance of the objective of the study.

$$
\begin{gathered}
\text { Model 1: } \log (\mathrm{REM})=\alpha_{0}+\alpha_{1} \log (\mathrm{MIG})+\alpha_{2} \log (\mathrm{EXC})+\alpha_{3} \log (\mathrm{GDPd})+\alpha_{4} \log (\mathrm{GDPh})+\alpha_{5} \log (\mathrm{PP})+ \\
\qquad \begin{array}{c}
\alpha_{6} \log (\text { skilledlabor })+\alpha_{7} \log (\text { unskilledlabour }) \\
\text { Model 2: } \log (\mathrm{REM})=\beta_{0}+\beta_{1} \log (\mathrm{DGPd})+\beta_{2} \log (\mathrm{PP})+\beta_{3} \log (\mathrm{EXC})+\beta_{4} \log (\text { unskilledlabour })
\end{array}
\end{gathered}
$$

Here,

$\log (\mathrm{EXC})=$ Log of exchange rate;

$\log ($ REM $)=$ Log of remittance inflow;

$\log (\mathrm{GDPh})=$ Log of simple average of six country's GDP;

$\log (\mathrm{GDPd})=\log$ of domestic GDP;

$\log (\mathrm{MIG})=\mathrm{Log}$ of number of person migrated;

$\log (\mathrm{PP})=\mathrm{Log}$ of petroleum price;

$\log$ (skilledlabor) $=$ Log of skilled labor migrated;

$\log$ (unskilledlabor) $=$ Log of unskilled labor migrated .

In order to mitigate the problem of irrelevant variable, model 2 has been estimated. Empirical test justifies the irrelevance of several variables included in model 1. Ordinary least square (OLS) method has been used to estimate the proposed models above. In this context, statistical software E-views 7 has been used for estimation purposes.

\subsection{ADF Unit Root Test}

Test for stationarity of data is very important in time series data because of the possibility of spurious regression. A random time series $Y_{t}$ is said to be stationary if its mean and variance are constant over time and the value of covariance between two time periods depends only on the distance between the two time periods and not on the actual time at which the variance is computed (Gujarati, 1995). Augmented Dickey-Fuller (ADF) unit root test has been used to check whether the variables are integrated.

Here, the null and alternative hypotheses are:

$\mathrm{H}_{0}$ : The residual series has a unit root (remittance, migration, petroleum price, skilled labor, unskilled labor, GDP host countries, GDP domestic countries series are not co-integrated).

$\mathrm{H}_{\mathrm{a}}$ : The residual series has no unit root (remittance, migration, petroleum price, skilled labor, unskilled labor, GDP host countries, GDP domestic countries series are co-integrated). 
Table 4. ADF test results for a unit root on the level and first difference of the original series

\begin{tabular}{|c|c|c|c|c|c|}
\hline Variable & ADF test statistic & p-value & $5 \%$ critical value & $10 \%$ critical value & Decision \\
\hline $\log (\mathrm{REM})$ & -1.56 & 0.49 & -2.95 & -2.61 & Non-Sationary \\
\hline$\Delta \log (\mathrm{REM})$ & -4.42 & 0.0014 & -2.95 & -2.62 & Stationary \\
\hline $\log (\mathrm{EXC})$ & -2.37 & 0.158 & -2.96 & -2.62 & Non-stationary \\
\hline$\Delta \log (\mathrm{EXC})$ & -3.88 & 0.005 & -2.96 & -2.62 & Stationary \\
\hline $\log (\mathrm{MIG})$ & -1.54 & 0.499 & -2.96 & -2.62 & Non stationary \\
\hline$\Delta \log (\mathrm{MIG})$ & -4.82 & 0.000 & -2.96 & -2.62 & Stationary \\
\hline $\log (\mathrm{PP})$ & -0.61 & 0.855 & -2.95 & -2.61 & Non-stationary \\
\hline$\Delta \log (\mathrm{PP})$ & -5.66 & 0.000 & -2.95 & -2.61 & Stationary \\
\hline $\log (\mathrm{GDPh})$ & -2.93 & 0.05 & -2.95 & -2.61 & Non-stationary \\
\hline$\Delta \log (\mathrm{GDPh})$ & -3.89 & 0.005 & -2.95 & -2.61 & Stationary \\
\hline $\log (\mathrm{GDPd})$ & 0.45 & 0.982 & -2.95 & -2.61 & Non-stationary \\
\hline$\Delta \log (\mathrm{GDPd})$ & -4.82 & 0.000 & -2.95 & -2.61 & Stationary \\
\hline $\log$ (skilledlabor) & -1.98 & 0.290 & -2.95 & -2.61 & Non-stationary \\
\hline$\Delta \log ($ skilledlabor $)$ & -6.79 & 0.000 & -2.95 & -2.61 & Stationary \\
\hline Log(unskilledlabor) & -1.79 & 0.37 & -2.95 & -2.61 & Non-stationary \\
\hline$\Delta \log ($ unskilledlabor) & -5.05 & 0.000 & -2.95 & -2.61 & Stationary \\
\hline
\end{tabular}

Note. $\Delta$ means first difference.

The decision rule here is if the $p$-value from ADF test $>0.05$ then null hypothesis will not be rejected. Otherwise, the null hypothesis will be rejected. Rejection of the null hypothesis would mean that all the variables are co-integrated.

The results of the ADF for the variables in their levels and first differences are reported in Table-4. Reported $\mathrm{ADF}$ test indicates that none of the variables represents a stationary process in level form but they are stationary in the first differences which is statistically significant at $5 \%$ level of significance.

\section{Empirical Results}

\subsection{Ordinary Least Squares Estimation Output}

Table 5 documents the estimation output of model 1.

Table 5. Regression results for model 1

\begin{tabular}{lllcc}
\hline & \multicolumn{5}{c}{ Model-1 } \\
\hline Variable & Coefficient & Std. Error & t-statistic & Prob. \\
\hline Constant & -29.65970 & 14.72750 & -2.013898 & 0.0545 \\
$\log (\mathrm{MIG})$ & -0.321109 & 0.214995 & -1.493560 & 0.1473 \\
$\log (\mathrm{EXC})$ & 1.225503 & 0.469238 & 2.611687 & 0.0148 \\
$\log (\mathrm{GDPh})$ & 1.030388 & 0.693180 & 1.486465 & 0.1492 \\
$\log (\mathrm{GDPd})$ & 0.509654 & 0.619773 & 0.822323 & 0.4184 \\
$\log (\mathrm{PP})$ & 0.368220 & 0.100239 & 3.673409 & 0.0011 \\
$\log ($ skilledlabor $)$ & 0.080695 & 0.138758 & 0.581552 & 0.5659 \\
$\log ($ unskilledlabor $)$ & 0.320093 & 0.188004 & 1.702583 & 0.1006 \\
R-squared & 0.992236 & Adjusted R-squared & 0.990146 \\
F-statistic & 474.7039 & Durbin-Watson & 1.295565 \\
Prob(F-statistic) & 0.00000 & Dependent variable & $\log (\mathrm{REM})$ \\
\hline
\end{tabular}

From the above results it is clear that petroleum price significantly influences remittance. Exchange rate also shows significant result. Migration shows negative impact on remittance but it is not a significant one. Though all other variables show expected sign but from the view of significance we may ignore all other variables except exchange rate and petroleum price. Durbin-Watson value confirms that the model is not spurious and shows $99 \%$ fitness.

As a better counterpart, Model 2 has been estimated. Estimation outputs corresponding to the following model are summarized in Table 6. 


$$
\log (\mathrm{REM})=\beta_{0}+\beta_{1} \log (\mathrm{DGPd})+\beta_{2} \log (\mathrm{PP})+\beta_{3} \log (\mathrm{EXC})+\beta_{4} \log (\text { unskilledlabour })
$$

Table 6. Regression results for model 2

\begin{tabular}{lllll}
\hline Variable & Coefficient & Std. Error & t-statistic & Prob. \\
\hline Constant & -8.118167 & 1.001069 & -8.109496 & 0.0000 \\
Log(GDPd) & 1.230726 & 0.405932 & 3.031857 & 0.0050 \\
Log(PP) & 0.351748 & 0.100346 & 3.505355 & 0.0015 \\
Log(unskilledlabor) & 0.184625 & 0.102618 & 1.799140 & 0.0821 \\
Log(EXC) & 1.502729 & 0.401762 & 3.740350 & 0.0008 \\
R-squared & 0.990873 & Adjusted R-squared & 0.989656 \\
F-statistic & 814.2105 & Durbin-Watson & 1.084025 \\
Prob(F-statistic) & 0.000000 & Dependent variable & $\log (\mathrm{REM})$ \\
\hline
\end{tabular}

In model 2 every single variable shows significant result at $1 \%$ significant level except unskilled labor but it is acceptable at $10 \%$ level of significance. Model 2 shows that these four variables could independently explain about 99 percent variation in remittance inflow. If the coefficients of two models are examined, the effect of unskilled labor is now significant in Model 2 when migration, host country GDP and skilled labor variables are excluded.

The second column of Table-6 shows estimated coefficients of GDPd, PP, Unskilled labor and exchange rate. The explanation of the sign and magnitude of these coefficients and their implications are presented below.

The estimated co-efficient of Domestic country (GDPd) is positive (1.230726) and highly significant at less than 1 percent level of significance. The values of $t$-statistic and the probability of rejecting the null hypothesis, $\mathrm{H}_{0}: \beta_{1}$ $=0$, are 3.031857 and 0.0050 respectively. The positive coefficient suggests that an increase in domestic GDP increases remittance inflow in Bangladesh.

Here the main objective is to estimate $\beta_{2}$. As outlined above, it is expected that there would have a positive relationship between the price of crude oil (PP) and remittance inflow $\left(\beta_{2}>0\right)$. The coefficients of the oil price, that are the main focus of this study, in both specifications are positive and significant at 1 percent level of significance. The values of $t$-statistic and the probability of rejecting the null hypothesis, $\mathrm{H}_{0}: \beta_{2}=0$, are 3.505355 and 0.0015 respectively. The positive coefficient (0.351748) suggests that an increase in price of oil increases remittance inflow in Bangladesh. Theoretically a higher price of oil stimulates more investment and consequently higher economic growth. This increase in aggregate demand is coupled with a parallel increase in demand for labor (both skilled and unskilled) and is converted into more income for emigrants and outpouring in remittances.

Skill of labors considerably influences remittance inflow. As discussed earlier, most of the labour migrated is unskilled. As per the estimation result of Model-1 the relationship between skilled labour and remittance is positive but statistically insignificant. Conversely, unskilled labor in Model 2 shows significant relationship with t-statistic and probability of rejecting null hypothesis $\mathrm{H}_{0}: \beta_{3}=0$, are 1.79914 and 0.0821 respectively The positive coefficient $(0.184625)$ signifies that positive changes will happen for any positive changes in unskilled labor.

The elasticity of the remittance inflows with respect to exchange rate is 1.502729 , which is positive and greater than unity. The values of t-statistic and the probability of rejecting the null hypothesis, $\mathrm{H}_{0}: \beta_{4}=0$, are 3.740350 and 0.0008 (below 1\%). The effect of exchange rate is significant at less than 1 percent level of significance revealing that currency depreciation promotes inward remittances in Bangladesh. The depreciation of the home currency makes the citizen living abroad wealthier as it increases the purchasing power in the home country and provides incentives to buy goods including residential real estate. This has multiplier effects. This result is also consistent with Guljare Nabi (2011) but Nurnaher Rama (2012) found the relation insignificant.

\subsection{Cointegration Test}

Since the variables are integrated of order one, cointegration test has been performed in order to examine the cointegration between the variables, we use the Engle-Granger method. Engle-Granger test shows that the residual is stationary at the level form. Variables are cointegrated which indicates that the long run relationship exists among variables. Cointegration test results have been presented in Table 7. 
Table 7. Test for cointegration of all the variables series

\begin{tabular}{llll}
\hline Model Residuals & Data based value of the test statistic & Critical value at 5\% level & Results \\
\hline Constant and trend & -4.094032 & -2.951125 & Reject $\mathrm{H}_{0}$ \\
Conclusion & $\begin{array}{l}\text { The residuals series does not have a unit root. Hence, remittance, exchange rate, petroleum } \\
\text { price, unskilled labor, GDP domestic country series are cointegrated. }\end{array}$ \\
\hline
\end{tabular}

\subsection{Normality Test}

Normality tests are performed in order to determine whether a data set follows a normal distribution or not. If the distribution of the residuals is not normal, then obtained $t$-ratios are substandard and inferences may not be valid. Therefore, normality test has to be carried out with proper attention. The null hypothesis of this test is that the residual series is normally distributed.

Here Jarque-Bera $(\mathrm{JB})$ test statistic is the appropriate test statistic,

$$
J B=n\left[\frac{S^{2}}{6}+\frac{(K-3)^{2}}{24}\right]
$$

where S and K are Skewness and Kurtosis respectively. Figure 4 shows the result of normality test.

The decision rule here is-

- Perfectly Symmetric residuals will have zero skewness.

- For a normal distribution the kurtosis value is 3 .

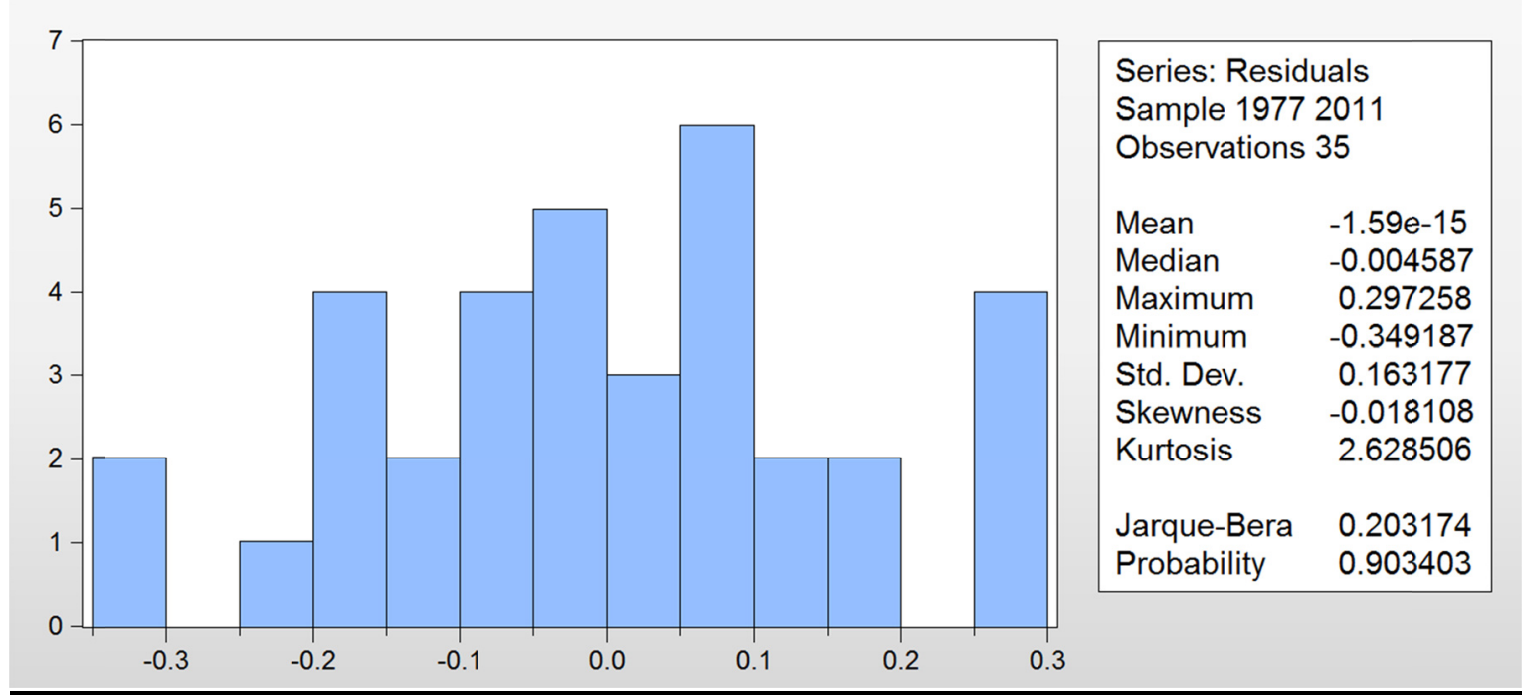

Figure 4. Test for normality the Jarque-Bera test

E-views estimation shows the skewness and kurtosis are -0.018108 and 2.628506 respectively. Jarque-Bera value is 0.203174 .

It can be concluded that null hypothesis cannot be rejected as JB statistics follow the chi-square distribution and the critical value is 5.991 at $5 \%$ level of significance with 2 degrees of freedom. So the residuals are normally distributed and inferences are valid.

\subsection{Heteroskedasticity Test}

White's Heteroskedasticity test has been performed to detect heteroskedasticity.

Null hypothesis $\mathrm{H}_{0}$ : there is no heteroskedasticity.

The decision rule here is if computed $\chi^{2}$ value $>$ critical value, null hypothesis will be rejected.

Estimated results obtained by using EViews7 are as follows: 
Table 8. Test for heteroskedasticity

\begin{tabular}{llll}
\hline Model & Obtained $\chi^{2}\left(\mathbf{n} * \mathbf{R}^{2}\right)$ & Critical value at different significance level & Decision \\
& 24.10225 & $23.6848(5 \%)$ & Reject Null \\
& & $26.8728(2 \%)$ & Accept Null \\
\hline \multirow{2}{*}{ Conclusion } & Obtained $\chi^{2}<$ Critical value of $\chi^{2}$ at $2 \%$ level of significance. So, the model is free from Heteroskedasticity \\
& at $2 \%$ level of significance. Finally, we can conclude that there is no Heteroskedasticity. \\
\hline
\end{tabular}

\subsection{Chow Break Point Test (Structural Stability Test)}

To apply Chow test, the data set has been divided into two parts - one is from 1977 to 1994 another from 1995 to 2011.

Hypotheses are:

$\mathrm{H}_{0}$ : no structural change;

$\mathrm{H}_{0}$ : structural change.

Test results are presented in Table 9 below.

Table 9. Chow breakpoint test (structural stability test)

\begin{tabular}{llccc}
\hline Model & F-Calculated value & Critical value at 5\% level & Prob F(5,25) & Status \\
\hline Constant and trend & 1.762749 & 2.60 & 0.1573 & Accept null \\
Conclusion & Here, F-critical $>$ F-calculated. Evidence does not support to reject the null hypothesis, thus we can say that \\
& null hypothesis of "No structural change" is accepted. That is our model is found structurally stable over time. \\
\hline
\end{tabular}

\subsection{Autocorrelation Test}

Autocorrelation refers to the correlation of a time series with its own past and future values. Autocorrelation is also sometimes called "lagged correlation" or "serial correlation", which refers to the correlation between members of a series of numbers arranged in time. Here we use Breusch-Godfrey Serial Correlation Lagrange Multiplier test for autocorrelation.

Null hypothesis $\mathrm{H}_{0}$ : There is no autocorrelation.

Results for autocorrelation test have been presented in Table 10 below.

Table 10. Test of autocorrelation

\begin{tabular}{lllll}
\hline Model & F-Calculated value & Critical value at 5\% level, F(1,29) & Prob. F (1,29) & Results \\
\hline Constant and trend & 5.710266 & 4.18296 & 0.0236 & Reject Null \\
Conclusion & $\begin{array}{l}\text { Here } p \text {-value } 0.02<0.05(5 \% \text { level of significance }) \text { and F-calculative value }>\text { F-critical value. Null } \\
\text { hypothesis is rejected. }\end{array}$ & & & \\
&
\end{tabular}

Since null hypothesis is rejected, there is autocorrelation. In the presence of autocorrelation, Heteroskedasticity and Autocorrelation Consistent (HAC) standard errors or Newey-West approach can be applied to obtain the correct standard error. HAC standard errors are rather larger than the incorrect standard errors. This implies if autocorrelation is not taken into account, the reliability of usual least square estimates would be overstated.

HAC standard errors and co-variance estimations are presented in Table 11 below.

Table 11. HAC standard errors and co-variance estimations

\begin{tabular}{ccccc}
\hline Variable & Coefficient & Std. Error & t-Statistic & Prob. \\
\hline C & -8.118167 & 0.930742 & -8.722249 & 0.0000 \\
LogGDPd & 1.230726 & 0.544843 & 2.258865 & 0.0313 \\
LogPP & 0.351748 & 0.123291 & 2.852995 & 0.0078 \\
Logunskilledlabor & 0.184625 & 0.126365 & 1.461050 & 0.1544 \\
LogEXC & 1.502729 & 0.418802 & 3.588159 & 0.0012 \\
\hline
\end{tabular}




\begin{tabular}{cccc}
\hline R-squared & 0.990873 & Adjusted R-squared & 0.989656 \\
Durbin-Watson & 1.084025 & & \\
\hline
\end{tabular}

\subsection{Multicollinearity Test}

Multicollinearity is a statistical phenomenon in which two or more explanatory variables in a multiple regression model are correlated, meaning that one can be linearly predicted from the others with a non-trivial degree of accuracy. In such instances a simple and effective way to detect Multicollinearity is to estimate the so called auxiliary regressions. For example, a general auxiliary regression for EXC is

$$
p p=\beta_{2} G D P d+\beta_{2} E X C+\beta_{5} \text { unskilledlabor }+\varepsilon_{t}
$$

If $R^{2}$ from this artificial model is above 0.80 , then it imply that a large portion of the variation in EXC is explained by variation in the other explanatory variable.

Estimated results are shown in Table 12 below.

Table 12. Multicollinearity test (auxiliary regressions)

\begin{tabular}{llll}
\hline \multirow{2}{*}{ Model } & Expected $\boldsymbol{R}^{2}$ & Artificial Model $\boldsymbol{R}^{2}$ & Decision \\
\cline { 2 - 4 } Conclusion & $>0.80$ & 0.747416 & Absence of Multicollinearity \\
& $\begin{array}{l}\text { We see that our artificial model's } R^{2} \text { is less than } 0.80 . \text { Therefore, } \\
\text { does not suffer from the problem of multicollinearity. }\end{array}$ & \\
\hline
\end{tabular}

\section{Conclusion and Policy Recommendation}

Remittance is a mammoth source of foreign currency reserve of Bangladesh. The analysis shows that unskilled labor migrants' are the principal source of remittance flows in Bangladesh. The remittances received from the migrant workers have been steadily increasing in recent years. In Bangladesh, the stability of remittance inflow has become an important issue. This paper along with trend analysis empirically examines various determinants of remittance inflow and finds that for the period 1977-2011, variables like exchange rate, economic activity of home country, skill of labors and most importantly petroleum price significantly influence remittance inflows.

Extant literatures do not identify the determinants of remittance empirically. Unlike the past studies our current paper investigates the determinants of remittance econometrically. We observe that if exchange rate depreciates remittance increases. This is because migrants have to send more money to their families to fulfill their livelihoods when cost of living increases. Besides, the petroleum price has considerable effect on remittance. Higher price of oil instigates more investment and consequently higher economic growth. The response of remittance to changes in price of oil is inelastic. Elasticity coefficient is found to be 0.35 .

Based on the findings, this paper concludes that Bangladesh as a labor abundant country can influence the inflow of remittances through appropriate policies. Government of Bangladesh should take necessary steps to enrich this sector by lessening the limitations on migration. This is to be mentioned here that Bangladeshi labour force gets easy access to a very small number of countries. Manpower export from Bangladesh is therefore prone to huge uncertainty due to narrow base. Policymakers should pay due attention to search new countries that will agree to hire the labour from Bangladesh.

There remains ample scope for further research on the current topic. Many other factors might have caused remittance inflow in Bangladesh. Our current study did not resolve a controversy regarding the pre-migration economic status of the migrants. Some argue that the poor section of the society opts for migration with the aim of improving their distressed status and others argue the opposite. The latter school opines that financially solvent ones can only afford the migration cost. Further research may be carried out by using cross-country data at the macro level and household surveys at micro level to resolve the controversy.

\section{References}

Alam, M. S. (2012). Microfinance institutions will be an important instrument to earn more remittance, send remittance and utilize remittance in Bangladesh. MPRA Paper No. 36459. http://dx.doi.org/10.2139/ssrn.2015978

Barai, M. K. (2012). Development dynamics of remittances in Bangladesh. SAGE Journals. http://dx.doi.org/10.1177/2158244012439073 
Barua, S., Majumder, M. A., \& Akhtaruzzaman, M. (2007). Determinants of workers' remittances in Bangladesh: An empirical study. Working Paper Series: WP 0713. Policy Analysis Unit. Bangladesh Bank.

Emmanuel, O., William, M. F., Gladys, C. A., \& Yuni, N. D. (2012). Microeconomic determinants of migrant remittances to Nigerian households. Economic Bulletin, 32(4), 3425-3438.

Faini, R. (2007). Remittances and the brain drain: Do more skilled migrants remit more? World Bank Economic Review, 21(2), 177-191. http://dx.doi.org/10.1093/wber/lhm006

Gujarati, D. N. (1995). Basic Econometrics (3rd ed.).

Hasan, M. M. (2008). The macroeconomic determinants of remittances in Bangladesh. MPRA Paper No. 27744.

Mahtab, K. H. (2012). Microeconomic determinants of workers' remittance in Bangladesh. Independent University of Bangladesh.

Manuel, O. (2009). Migration and remittances in times of recession: Effects on Latin American Economies. Inter-American Dialogue.

Nabi, M. G. (2011). An empirical inquiry into macroeconomic determinants of remittances inflow in Bangladesh. Research Department. Bangladesh Bank.

Naufal, G., \& Termos, A. (2009). The responsiveness of remittance to the oil price: The case of the GCC. IZA Discussion Paper No.4277. http://dx.doi.org/10.1111/j.1753-0237.2009.00166.x

Nurnaher, M. B., \& Rama, R. S. (2012). Behavior of remittance inflows and its determinants in Bangladesh. Working Paper Series: WP1202, Research Department, Bangladesh Bank.

Rahim, A. (2013). Foreign remittance income in Bangladesh: Opportunities and challenges. Asian Business Review, 2(2).

Ratha, D. (2004). Understanding the Importance of Remittances. World Bank, Migration Information Source, Feature story.

Roy, K. (2010). Remittance as a tool of economic development: Bangladesh perspective. Bangladesh Research Publications Journal, 4(3), 286-296.

Singh, R. J., Haacker, M., \& Lee, K. (2009). Determinants and macroeconomic impact of remittance in Sub-Saharan Africa. IMF Working Paper WP/09/216. http://dx.doi.org/10.5089/9781451873634.001

\section{Copyrights}

Copyright for this article is retained by the author(s), with first publication rights granted to the journal.

This is an open-access article distributed under the terms and conditions of the Creative Commons Attribution license (http://creativecommons.org/licenses/by/3.0/). 